IBM Unitcd Kingdom, Ltd., 101 Wigmore Street, London, W.1.

\section{Enzyme Chemistry of Phenolic Compounds}

A symposium. on "The Enzyme Chemistry of Phenolic Compounds", arranged by the Plant Phenolics Group of the University of Liverpool, will bo hold in the University during April 10-12. After an introductory address by Prof. N. A. Burges, papers to be rcad will include: purification of catechol oxidases (Dr. D. S. Bendall and R. P. F. Gregory); plant polyphenol-oxidasos and their relation with other oxidaso systems in plants (Dr. J. G. Boswell); tea polyphenol-oxidase (Dr. F. A. H. Roberts); phenol-oxidases in streptomycetes (Prof. E. Küster); tocopherols (Dr. J. Green); the role of ubiquinone and plastoquinone in plant motabolism (Prof. R. A. Morton); hydrolytic enzymos (Dr. J. B. Pridham); hydroxylation systems (Dr. J. B. Jepson); enzyme inhibition by phenolic compounds (A. IT. Williams); tannin inhibition of plant mitochondria (Dr. A. G. Hulme and Dr. J. D. Jones); biologieal oxidation of aromatic rings by micro-organisms (Prof. W. Charles Evans); aromatic-acid reducing systems in fungi (Dr. H. M. Hurst); some new enzymatic reaction of phenols (Dr. B. R. Brown). Further information can be obtained from Dr. H. M. Hurst, Dopartment of Botany, University of Liverpool.

\section{Food Supplies and Population Growth}

A conference on "Food Supplies and Population Growth", arranged by the Royal Statistical Society, is to be held at the London School of Economics on April 6. Subjects under discussion will include: population trends (Dr. B. Benjamin, General Register Office); estimation of food requirements (Dr. R. Passmore, University of Edinburgh); future sources of food supply - scientific problems (Dr. N. W. Pirie, Rothamsted Experimental Station); future sources of food supply-economic problems (Prof. C. G. Clark, University of Oxford). Further information can be obtained from the honorary secretary, Prof. P. Armitage, Royal Statistical Society, 21 Bentinck Street, London, W.1.

\section{The Royal Institution}

Mr. Trromas Martin, general secretary of the Royal Institution, 1929-50, has written a most attractive concise account of the Royal Institution (The Royal Institution. By Thomas Martin. Pp. 69. London: Royal Institution of Great Britain, 1961). With carefully chosen and admirable illustrations, Mr. Martin shows clearly how the Institution took its shapo under the influence of Rumford, Davy, Faraday, Tyndall, Dewar and Sir William Bragg, and the unique place it occupies among British scientific institutions. Its function could scarcely have been botter indicated or its past and potential contributions to tho advancement of science or enrichment of society, and the brief bibliography should induce some readers at least to go further into the story for themsolves.

\section{Announcements}

Mr. K. S. ImRIs, of the University of New England, Armidale, has been appointed by the Royal society to a Rutherford Scholarship, tenable for throo years, to work on a problern involving radar astronomy techniques at tho Nufficld Radio Astronomy Laboratories, Jodrell Bank Experimental Station, University of Manchester.
Tre Trustees of the Ramsay Memorial Fellowships Trust invite applications for two fellowships for advancod students of chemistry, each tenable for two years. Application forms, which should be returned before April 9, and further information can be obtained from the Joint Honorary Secretaries, Ramsay Memorial Fellowships Trust, University College, Gower Street, London, W.C.1.

The Royal Australian Chemical Institute invites applications from chemists who require assistance in meeting their travelling expenses in order to spend their sabbatical leave in an Australian chemical laboratory attached to a univorsity or the Commonwealth Scientific and Industrial Research Organiza. tion. The Institute is also prepared to arrange for visitors to travel within Australia. Further information can be obtainod from the Australian Scientific Liaison Office, Africa House, Kingsway, London, W.C.2.

The Easter congress of the Universities Federation for Animal Welfare is to be hold in Edinburgh during April 5-9. Further information can be obtained from tho Universities Federation for Animal Welfaro (Easter Congress), $7 a$ Lamb's Conduit Passage, London, W.C.1.

AN international conference on "Magnetic and Electric Resonance and Relaxation", arranged under the auspices of the Groupoment AMPERE and the Netherlands Physical Society, is to be held at Eindhoven during July 2-7. Further information can be obtained from Dr. D. J. Kroon, Philips Rescarch Laboratories, Eindhoven.

A symposium on "Post-Tertiary Speciation in Europe", arranged by the Systematics Association. is to be held in the University of Loicester during April 16-17. Further information can be obtained from Mr. Norman Tebble, Systematics Association. British Museum (Natural History), Cromwoll Road, London, S.W.7.

A symposium on "Some Problems in Communicating and Absorbing Technical Information", organized by the Technical Library and Information Service of the Hertfordshire County Council, is to be held at Hatfield College of Technology on March 27. Further information can be obtained from the county tochnical Iibrarian, G. H. Wright, Hatfield College of Technology, Hatfield, Herts.

A Menting of the Photoelectric Spectrometry (Yrroup is to be held in King's College, London, on March 16. The subject under discussion will be "Differential and Derivative Absorption Spectroscopy", and speakers will include: Dr. G. L. Brown (King's College, London); Dr. E. F. Daly (Unicam Instrumonts, Ltd., Cambridgo); Dr. G. H. Beaver (Medical Research Council, London); C. E. Kendall and D. W. Huke (Dunlop Research Centre, Birmingham); D. (*. Lloyd (Monsanto Chomicals, Ltd., Ruabon). Further information can be obtained from the secretary, Mr. K. A. Macdonald, Unicam Instruments, Ltd., York Street, Cambridge.

Erratym. The publishers of $A$ Hole in the Bottom of the Sea reviewed on p. 718 of the February 24 issue of Nature are Weidenfeld and Nicolson, Ltd., and not: Faber and Faber, Ltd., as stated. Furthermore, the price of the book is $25 \mathrm{~s}$. and not $42 \mathrm{~s}$. 